
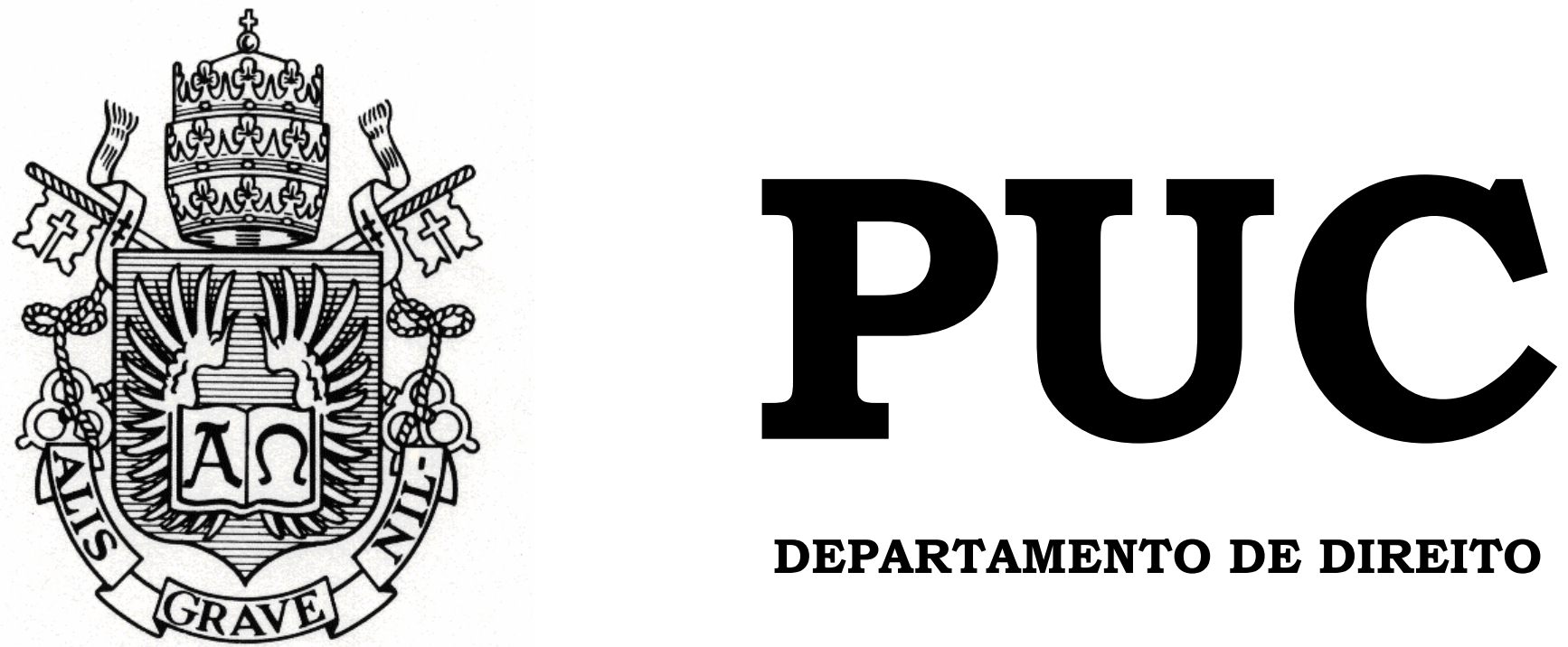

DEPARTAMENTO DE DIREITO

\title{
BIOCENTRISMO E A PROTEÇÃO JURÍDICA SOCIOAMBIENTAL
}

\author{
por
}

BRUNA GONÇALVES D’ ALMEIDA

ORIENTADOR(A): Danielle de Andrade Moreira 2005.1

PONTIFÍCIA UNIVERSIDADE CATÓLICA DO RIO DE JANEIRO

RUA MARQUÊS DE SÃO VICENTE, 225 - CEP 22453-900

RIO DE JANEIRO - BRASIL 


\title{
BIOCENTRISMO E A PROTEÇÃO JURÍDICA SOCIOAMBIENTAL
}

\author{
por \\ BRUNA GONÇALVES D' ALMEIDA
}

Monografia apresentada ao

Departamento de Direito da

Pontificia Universidade Católica

do Rio de Janeiro (PUC-Rio) para

a obtenção do Título de Bacharel em Direito.

Orientador(a): Danielle de Andrade Moreira 
Dedico humildemente esta monografia aos meus queridos professores de Direito Ambiental que tanto admiro e tenho enorme apreço:

Danielle de Andrade Moreira

Fernando Walcacer

Oscar Graça Couto 


\section{ÍNDICE}

INTRODUÇÃO

1. COSMOVISÕES: A CAMINHO DO BIOCENTRISMO JURÍDICO.....

1.1 Emergência Ambiental

1.2 Ética e Meio Ambiente

1.3 Ética Ambiental e Ciência Jurídica: antropocentrismo $\mathrm{x}$ biocentrismo

2. CONCEPÇÕES DE MEIO AMBIENTE

2.1 Sentido e abrangência do termo

2.2 Conceito legal de meio ambiente

2.3 Aspectos do Meio Ambiente: natural, cultural, urbano ou artificial e do trabalho

3. SOCIOAMBIENTALISMO

3.1 Proteção jurídica da sociodiversidade e do patrimônio cultural

3.2 Princípio do respeito à identidade, cultura e interesses das comunidades tradicionais e grupos formadores da sociedade 


\section{RESUMO}

O presente trabalho trata da necessidade de uma nova ética ambiental que rompa com os paradigmas obsoletos do passado, incorporando ao Direito uma cosmovisão biocêntrica. Paralelamente, o movimento socioambiental vai de encontro a essa nova forma de se relacionar dos seres humanos com toda a comunidade biótica e abiótica, valorizando a sociodiversidade e o patrimônio cultural existente no mundo. 


\section{INTRODUÇÃO}

Com os passar dos anos as questões ambientais vêm ganhando maior visibilidade e importância aos olhos humanos. Aos poucos vamos conseguindo difundir e consolidar uma visão mais sistêmica e ampla de meio ambiente. Neste sentido, o conceito de meio ambiente também do ponto de vista jurídico assume novos escopos alicerçados na necessidade de proteção de direitos substancialmente diferenciados dos direitos tradicionalmente regulados. A noção mais abrangente das especificidades inerentes à proteção jurídica do ambiente deve ser levada em conta para que se consiga dar real eficácia a sua tutela.

O Direito Ambiental, enquanto ramo do direito que regula as relações entre o ser humano e a Natureza, necessita e invoca mudanças nos esquemas jurídicos tradicionais, que se mostram freqüentemente insuficientes para resolver muitas das questões jurídico-ambientais apresentadas, a fim de garantir um convívio harmônico e indispensável à continuidade da vida humana e de outros seres vivos no Planeta.

Diante disso, o presente trabalho tem como objetivo explicitar os postulados éticos envolvidos na complexa relação ser humano natureza, as diferentes tendências do pensamento ambiental e suas conseqüências no campo jurídico. Somente a reflexão ética nos possibilita e impulsiona a uma profunda mudança de mentalidade e comportamento fundamental à sustentabilidade do Planeta. 
Cada vez mais se mostra insuficiente para a manutenção da qualidade ambiental a concepção clássica antropocêntrica de se pensar o meio ambiente, de modo que faz parte crucial desse estudo investigar os fundamentos da concepção antropocêntrica do Direito e as discussões mais recentes em torno de uma ética biocêntrica.

A partir disso, se quer consolidar o entendimento do ser humano como parte dessa imensa biodiversidade do Planeta, valorizando o caráter cultural do meio ambiente e a sociodiversidade que está imbricada no conceito de biodiversidade.

Para alcançar tais propósitos, a primeira parte do trabalho tratará do processo que fez emergir a preocupação ambiental e a tentativa de transição do paradigma antropocêntrico-utilitarista para o biocêntrico, explicitando os fundamentos éticos consubstanciados.

Em seguida, no segundo capítulo, pretende-se expor as diferentes concepções de meio ambiente, seus alcances e limitações, o enfoque jurídico dado ao tema, considerando de fundamental importância o capítulo da nossa Constituição Federal de 1988 dedicado ao Meio Ambiente e a definição que já nos era fornecida pela Lei $6.938 / 81$, que trata da Política Nacional do Meio Ambiente.

Por fim, no último capítulo, será analisado o socioambientalismo à luz do Direito, respaldado na Constituição Federal de 1988, que inclui a preservação e a valorização da sociodiversidade e do patrimônio cultural 
como elementos essenciais à sadia qualidade de vida e o que garante nossa sobrevivência histórica. Ainda nesse capítulo não se podia deixar de destacar um dos princípios fundamentais do direito ambiental relacionado a esse estudo, o princípio do respeito à identidade, cultura e interesses das comunidades tradicionais e dos grupos formadores da sociedade brasileira.

Com isso, a intenção é provocar uma reflexão sobre a relação entre natureza e cultura, entendendo que o ethos humano resulta da interação com a natureza e com a sociedade, sendo, assim, impossível pensar em construir uma ética ambiental desvinculada da problemática social. ${ }^{1}$ Os problemas do meio ambiente e do desenvolvimento sustentável se encontram diretamente relacionados com os problemas da pobreza, satisfação das necessidades básicas, alimentação, saúde e habitação, e de uma matriz energética que privilegie as fontes renováveis no processo de inovação tecnológica. ${ }^{2}$ Nesse sentido, ULRICH BECK ressalta que:

\begin{abstract}
"não se pode mais pensar na natureza de forma apartada da sociedade e vice-versa, pois os problemas do meio ambiente não são problemas do entorno, mas em sua gênesis e em suas conseqüências, problemas sociais, do ser humano, de sua história, de suas condições de vida, de sua concepção de mundo e da realidade, de seu ordenamento econômico, cultural e político". ${ }^{3}$
\end{abstract}

\footnotetext{
${ }^{1}$ SIQUEIRA, Josafá Carlos de. Ética e Meio Ambiente. $2^{\text {a }}$ edição. São Paulo: Edições Loyola, 2002, p.20.

${ }^{2}$ GUIMARÃES, Roberto. “A assimetria de interesses compartilhados: América latina e a agenda global do meio ambiente“. In Ecologia e política mundial. LEIS, H. R. (org.). Rio de Janeiro, Vozes/Fase, 1991.

3 BECK, Ulrich. La sociedad Del riesgo: hacia uma nueva modernidad. Barcelona, Buenos Aires, México: Paidós, 1998, p. 90
} 
Nesse contexto, por quê falar em Ética e, principalmente, em Ética Ambiental? Primeiramente, antes de adentrar na problemática que perpassa o tema, cabe ressaltar o significado da palavra ética, que vem do grego ethos, e significa: modo de ser, caráter, enquanto forma de vida do ser humano. O que faz com que o ethos animal se diferencie do nosso ethos é o fato de que o primeiro é determinado unicamente pela natureza e já o ethos humano vai além do caráter instintivo e repetitivo de ethos animal, pois possui também um caráter reflexivo e criativo. ${ }^{4}$ Por isso é que podemos refletir, repensar, criar e recriar novas práxis ambientais que resultem em posturas éticas transformadoras e libertadoras que, embora pequenas e geograficamente restritas, acabam irradiando e iluminando o horizonte mais amplo e universal. ${ }^{5}$

Ao mesmo passo, o Direito Ambiental também precisa criar mecanismos que realmente possibilitem a defesa e a preservação do meio ambiente sadio para as presentes e futuras gerações e rompa com a tradicional visão estritamente utilitarista da natureza, incapaz de atender aos anseios atuais da espécie humana no sentido de manutenção de um meio ambiente ecologicamente equilibrado para todas as formas de manifestação de vida no Planeta.

\footnotetext{
${ }^{4}$ SIQUEIRA, Josafá Carlos de. Ob. cit., p. 20.

${ }^{5}$ Ibidem, p. 20.
} 


\section{1 - COSMOVISÕES: A CAMINHO DO BIOCENTRISMO JURÍDICO}

\section{1 - Emergência Ambiental}

As preocupações com o meio ambiente ganharam enfoque principalmente a partir dos anos $70^{6}$, com a intensificação dos problemas sócioambientais que começavam a ser deflagrados em todo mundo, como: os processos de urbanização acelerada; o crescimento e a desigual distribuição demográfica; a expansão descontrolada do uso de energia nuclear; o consumo excessivo de recursos não-renováveis; os fenômenos crescentes de perda e desertificação do solo; a contaminação dos recursos naturais; o desflorestamento; a redução da biodiversidade e da diversidade cultural; a geração do efeito estufa e a redução da camada de ozônio e suas implicações sobre o equilíbrio climático. ${ }^{7}$

A multiplicação de acidentes e problemas ambientais, conforme o mencionado anteriormente, e a ação de movimentos ecológicos ${ }^{8}$ compõem uma força crítica aos modelos de desenvolvimento industrial, despertando para a necessidade e urgência de uma nova consciência,

\footnotetext{
${ }^{6}$ A primeira onda ambiental foi grandemente influenciada pelo debate generalizado que, ao final dos anos 60, buscava propor formas alternativas de organização social e de comportamento. (In Introdução ao Gerenciamento de Recursos Hídricos / Arnaldo Augusto Setti:...[et al.]. Brasília: Agência Nacional de Energia Elétrica; Agência Nacional de Águas, 2001. p. 242)

${ }^{7}$ LIMA, Gustavo F. da Costa. Revista Eletrônica "Política e Trabalho" - setembro 1997 / p. 201-202.

${ }^{8}$ FRIJOF CAPRA chama a atenção par ao fato de que os estudos no ramo da biologia sobre a relação entre os seres vivos e o meio ambiente é tema historicamente recente: a palavra "ecologia" foi cunhada pelo biólogo alemão Ernst Haeckel, em 1866, que utilizou o vocábulo grego oikos (casa), ao propor uma disciplina científica com o objetivo de estudar a função das espécies animais com o seu mundo orgânico e inorgânico: em suma, o estudo das relações que interligam todos os membros do Lar Terra. (CAPRA, Frijof. A Teia da Vida. São Paulo: Cultrix, 1999. p. 43)
} 
atenta a dimensão ambiental da realidade. Os reclamos da sociedade civil organizada foram paulatinamente pressionando a incorporação da questão ambiental aos programas de governo nacionais, ao sistema político-partidário e à agenda dos organismos internacionais.

Nesse contexto a Conferência Internacional para o Meio Ambiente Humano, promovida pelas Nações Unidas - ONU, em 1972, na Suécia, é um marco histórico-político de uma série de iniciativas e eventos nacionais e internacionais que passaram a dar um novo tratamento aos temas ambientais. ${ }^{9}$ Cabe ressaltar a importância dessa conferência para a adoção de um conceito amplo e sistêmico de meio ambiente humano, tendo como produto a Declaração de Estocolmo, a qual já se adotam importantes referências à qualidade de vida e ao bem-estar. ${ }^{10}$

Na esteira da Conferência de Estocolmo registram-se a criação do PNUMA - Programa das Nações Unidas para o Meio Ambiente, e de diversos outros programas que refletem a preocupação ecológica, sobretudo com a vulnerabilidade dos ecossistemas naturais.

Em 1987 foi publicado um relatório intitulado "Nosso Futuro Comum" e conhecido como Relatório Brundtland ${ }^{11}$, sobre o meio

\footnotetext{
9 Nesse mesmo ano, o Clube de Roma publicou um estudo chamado "Os limites do crescimento", que analisava a situação ambiental e, a partir disso, se começou a atentar para os problemas levantados.

${ }^{10}$ É a partir da Declaração de Estocolmo, de 1972, que o meio ambiente deixa de ser enfocado de maneira restrita e isolada em cada um dos seus "microbens", para passar a ser reconhecido como macrobem, no sentido de se constituir como o conjunto de relações que se estabelece entre os seres vivos e entre estes e o meio físico em que vivem.
} 
ambiente global. O relatório parte do pressuposto da possibilidade e da necessidade de conciliar crescimento econômico e conservação ambiental e divulga o conceito de desenvolvimento sustentável e um conjunto de premissas que, desde então, têm orientado os debates sobre o desenvolvimento e a questão ambiental.

O discurso se orienta no sentido da sustentabilidade e do desenvolvimento, e da necessidade de tratar o meio ambiente numa perspectiva multidimensional que a um só tempo articula economia, ecologia e política, numa visão integrada, que supera abordagens unilaterais e as explicações reducionistas e simplificadoras do passado. ${ }^{12}$ Com isso se apresenta uma filosofia de desenvolvimento que combina eficiência econômica com prudência ecológica e justiça social. ${ }^{13}$

Nesse sentido, cabe ressaltar a importância da compreensão multidimensional da realidade que se contrapõe à divisão cartesiana entre matéria e mente, e teve um efeito profundo sobre o pensamento

\footnotetext{
${ }^{11}$ O relatório recebeu esse nome por conta da Primeira-Ministra da Noruega que se chamava Gro Harlem Brundtland, que foi quem presidiu a Comissão Mundial sobre Meio Ambiente e Desenvolvimento, estabelecida para delinear estratégias ambientais para os próximos anos. Em 1985, a Assembléia Geral das Nações Unidas atribuiu ao Programa das Nações Unidas para o Meio Ambiente essa tarefa e com isso foi estabelecida uma Comissão Mundial sobre Meio Ambiente e Desenvolvimento. ((In: Introdução ao Gerenciamento de Recursos Hídricos / Arnaldo Augusto Setti:...[et al.]. Brasília: Agência Nacional de Energia Elétrica; Agência Nacional de Águas, 2001. p. 245)

${ }^{12}$ LIMA, Gustavo F. da Costa. Ob. Cit., p.201-202.

13 O conceito de sustentabilidade inova também ao valorizar os problemas das relações norte-sul e sobretudo as especificidades dos países mais pobres, quando relaciona pobreza, riqueza e degradação, quando atenta para as implicações adversas da dívida externa no contexto sócio-ambiental desses países, inclusive reconhecendo a desigualdade norte-sul e a maior responsabilidade relativa dos países do norte na construção de um desenvolvimento sustentável. (In LIMA, Gustavo F. da Costa. Ob. Cit., p.201-202).
} 
ocidental. Descartes equiparava as várias funções biológicas do corpo às peças de um relógio. Via o universo material como uma máquina, onde a natureza funcionava de acordo com leis mecânicas, governada por leis matemáticas exatas, e tudo no mundo material podia ser explicado em função da organização e do movimento de suas partes.

Esse quadro mecânico da natureza tornou-se o paradigma dominante da ciência no período que se seguiu a Descartes. A concepção cartesiana do universo como sistema mecânico forneceu uma sanção científica para a manipulação e a exploração da natureza que se tornaram típicas da cultura ocidental. Até hoje, ainda se tem muita dificuldade em romper com essa forma de pensamento fragmentada, que muito contribuiu para as conquistas passadas, mas que não atende às necessidades do presente.

Essa orientação metodológica acompanhou as principais vertentes do pensamento moderno a partir do final do século $X V I$ e o que caracterizou a investigação filosófica do século XVII. Fez-se presente à perspectiva empirista proposta por Francis Bacon, a preconizar uma ciência sustentada pela observação e pela experimentação, autor da frase "Saber é Poder", que influenciou toda uma forma de dominação e alteração da natureza baseada na premissa de que a natureza deveria ser torturada para liberar os seus segredos. No mesmo sentido, inaugurando o racionalismo moderno, Descartes busca na razão os recursos para a recuperação da certeza científica, que as matemáticas encarnavam de maneira exemplar pela certeza e evidência de suas 
razões, o que o levará a escrever mais tarde, sua principal obra, o Discurso do Método.

Já de início pode-se dizer que o método analítico de raciocínio é provavelmente a maior contribuição de Descartes à ciência, tendo se tornado uma característica essencial do moderno pensamento científico e extremamente útil no desenvolvimento de teorias científicas e na concretização de complexos projetos tecnológicos. Por outro lado, a excessiva ênfase dada ao método cartesiano levou à fragmentação característica do nosso pensamento, em geral, e das nossas disciplinas acadêmicas, e levou à atitude generalizada de reducionismo na ciência a crença em que todos os aspectos dos fenômenos complexos podem ser compreendidos se reduzidos às suas partes constituintes.

Em contraste com a concepção mecanicista cartesiana, a visão de mundo que está surgindo a partir da física moderna pode ser caracterizada por palavras como orgânica, holística e ecológica. Aos poucos, a visão de mundo mecanicista da ciência cartesiana vai sendo deixada para trás, em função de uma realidade que já não pode ser entendida pela aplicação de conceitos de uma visão de mundo obsoleta e fragmentada. Hoje já se tem mais clareza de que se vive num mundo globalmente interligado, no qual os fenômenos biológicos, psicológicos, sociais e ambientais são todos interdependentes. 


\section{2 - Ética e Meio Ambiente}

Apesar da tomada de consciência cada vez maior acerca da emergência e da difusão dos problemas sócioambientais, esse despertar de uma nova consciência ecológica ainda não se refletiu em mudanças significativas nos rumos das políticas governamentais e dos estilos de vida individuais. ${ }^{14}$ Ainda deixa muito a desejar a forma de relacionamento entre sociedade e natureza, e a desarticulação entre os diversos saberes.

No entanto, percebe-se que, aos poucos, o movimento ambientalista vai ganhando mais espaço, ampliando seu foco de atenção para incluir na pauta de discussões outros pontos extremamente relevantes e atuais, como a ecologia política, a questão demográfica, a relação entre pobreza e ecologia, a questão técnico-científica, as relações norte-sul, a busca de um novo modelo de desenvolvimento e, principalmente, a questão ética. ${ }^{15}$

CRISTOVAM BUARQUE chama a atenção para as limitações das análises econômicas que têm a tendência de reduzir a complexidade do real e fragmentar a globalidade dos fatos, que se expressam na

\footnotetext{
${ }^{14}$ LIMA, Gustavo F. da Costa. Ob. Cit., p.201-202.

${ }^{15}$ VIOLA, Eduardo \& LEIS, Hector. "Desordem global da biosfera e a nova ordem internacional: o papel organizador do ecologismo". In Ecologia e Política Mundial. Org.: LLEIS. H. R. Rio de Janeiro: Vozes/FASE, 1991.
} 
perspectiva imediatista, e de curto prazo, incompatíveis com o longo prazo das mudanças e dos ciclos naturais. ${ }^{16}$

Falar em ética é essencial para se pensar uma forma diferenciada de relacionamento do ser humano com o seu entorno, do modo de o mesmo estar no Planeta. Nas palavras de JOSAFÁ CARLOS DE SIQUEIRA, SJ:

\begin{abstract}
"somente a dimensão ética do meio ambiente pode oferecer às pessoas um conjunto de princípios e condutas normativas, melhorando as relações entre o cidadão, a sociedade e o espaço ambiental". ${ }^{17}$
\end{abstract}

Segundo ADOLFO SANCHES VAZQUEZ, a ética é uma ciência da moral e pode ser definida como: "a teoria ou ciência do comportamento moral dos homens em sociedade". ${ }^{18}$ Desde os filósofos dos primeiros séculos, Sócrates e Platão e, mais tarde os seus discípulos, refletiram sobre a Ética e concluíram que ela é ligada à política, é racionalista e se explica pela virtude, cujo objetivo é o bem - o ser humano é visto como um animal político e social que usa a Ética, refletida na razão e na virtude, para alcançar a felicidade. ${ }^{19}$ Com o Cristianismo encontramos a

\footnotetext{
${ }^{16}$ BUARQUE, Cristovam. "A desordem do progresso: o fim da era dos economistas e a construção do futuro“. Rio de Janeiro: Paz e Terra, 1990.

${ }^{17}$ SIQUEIRA, Josafá Carlos de. Op. cit., p. 09.

${ }^{18}$ VASQUEZ, Adolfo Sanches. Ética. Ed. Civilização Brasileira, 25a edição. 2004. p.45.

19 SANTOS JR., Hidejal N. Artigo: Ética Ambiental: Paradigma ou Conduta Profissional. Endereço eletrônico: http://www.saude.inf.br/etica.htm
} 
Ética definida como um conjunto de verdades, mandamentos e condutas revelados de Deus e seguido pelos seres humanos.

Atualmente as discussões sobre ética envolvem temas como a Bioética, entre outras questões que requerem um posicionamento crítico e reflexivo da sociedade e que muitas vezes é relegado a segundo plano. Em sua relação com o direito, a Ética ficou durante muito tempo reduzida a preceitos delimitadores das relações profissionais, aos Códigos Éticos, restando apenas a ética normatizada e direcionada às profissões, não focalizando uma ética universal. ${ }^{20}$

No entanto, tendo em vista os novos conhecimentos científicos e a degradação desmedida dos ecossistemas, cada vez mais somos impelidos a rever nossa ação predatória e, conseqüentemente, nosso comportamento diante do Planeta, de forma a não comprometer a continuidade da vida. Essa consciência e visão global nos permitem desenvolver uma nova linha de conduta ética em relação ao meio ambiente, passando a entender melhor nossa atuação e responsabilidade frente aos demais seres vivos e a necessidade de uma visão holística do mundo e da vida.

Como destaca ADAUTO CARDOSO, "a base de pensamento da utopia ecológica vem de um conjunto de proposições de caráter éticofilosófico extremamente críticas com relação aos padrões de

\footnotetext{
${ }^{20}$ Artigo: Ética ambiental. Endereço eletrônico: http://www.aultimaarcadenoe,com/direitoetica.htm
} 
desenvolvimento econômico e social da era moderna". ${ }^{21}$ Aos poucos, o ideal ambientalista caminha para uma retomada do prestígio da teoria ética reformulada com base em conceitos éticos universais, que conduzem à tomada de consciência a respeito das conseqüências da crise ambiental. ${ }^{22}$ Esse reconhecimento traz fundamentos para a criação de uma base sólida de reflexões a respeito de se construir preposições éticas que sejam criticamente confrontadas com os padrões atuais de desenvolvimento econômico e social. ${ }^{23}$

Como destaca DANIELLE DE ANDRADE MOREIRA, "observa-se à construção de um cenário onde se alteram os paradigmas e fundamentos éticos relacionados aos comportamentos humanos perante a natureza, o que traz consigo a identificação de valores não econômicos no meio ambiente e, assim, a sua caracterização como bem de ampla dimensão, essencial ao pleno desenvolvimento humano das presentes e futuras gerações". ${ }^{24}$ Paralelamente, o direito a um meio ambiente ecologicamente equilibrado, essencial à sadia qualidade de vida, amplia o conteúdo dos direitos humanos e o próprio conceito de cidadania $^{25}$, à

\footnotetext{
${ }^{21}$ CARDOSO, Adauto. "A Utopia em Construção: Modernidade, ecologia e urbanização". In Brasil Território da Desigualdade. Org.: ANA CLARA TORRES e ROSÉLIA PIQUET. Rio de Janeiro: Jorge Zahar Editores, 1991, p. 114.

${ }^{22}$ MOREIRA, Danielle de Andrade. Tese de mestrado apresentada ao programa de pós-graduação em Dirito da UERJ. 2002, p. 20.

${ }^{23}$ Ibidem, p. 20.

${ }^{24}$ Ibidem, p. 08.

${ }^{25}$ BORGES, Roxana Cardoso Brasileiro. "Direito Ambiental e Teoria Jurídica no final do século XX". In O novo em Direito Ambiental. Org.: MARCELO DIAS VARELLA e ROXANA CARDOSO BORGES. Belo Horizonte: Del Rey, 1998, p. 13.
} 
medida que impulsiona o exercício cidadão, em prol de um bem, nos moldes do texto constitucional, "de uso comum do povo", compartilhado por toda a coletividade.

Da mesma forma, destaca-se a necessidade de que o desempenho das funções públicas na gestão ambiental seja sempre orientado por princípios éticos que garantam o alcance dos objetivos sociais almejados, assim como a cooperação entre Estado e indivíduo na defesa e preservação do meio ambiente sadio constituem um imperativo tanto ao Poder Público como à coletividade. ${ }^{26}$

\title{
Nesse sentido DANIELLE DE ANDRADE MOREIRA ao citar ÉDIS MILARÉ destaca:
}

\begin{abstract}
"Numa sociedade em que a consciência e o exercício da cidadania são ainda débeis e vacilantes, as manipulações contra o Meio Ambiente, os abusos antiecológicos do poder, a discricionariedade e favorecimentos ilícitos, a prepotência e o cinismo são facilmente constatáveis e passam batidos com carimbos e chancelas. A malandragem disfarçada é elevada à categoria de louvável esperteza e pouco se questiona o aspecto de uma Ética sócioambiental nesses casos". ${ }^{27}$
\end{abstract}

\footnotetext{
${ }^{26}$ MOREIRA, Danielle de Andrade. Ob. cit. p. 33. O texto constitucional é muito claro a esse respeito, impondo explicitamente ao Poder Público e à coletividade o dever de defender e preservar o meio ambiente para as presentes e futuras gerações. Ver art. 225 da Constituição Federal da República Federativa do Brasil de 1988.

${ }^{27}$ MOREIRA, Danielle de Andrade. Ob. cit. , p. 33
} 


\section{3 - Ética Ambiental e Ciência Jurídica: antropocentrismo X biocentrismo}

A partir do que foi exposto no tópico anterior, é preeminente a necessidade de uma Ética Ambiental que provoque a consciência do ser humano em relação à natureza, entendendo que este faz parte da natureza e não é o seu dono, não a tem para servi-lo, mas para que ele sobreviva em harmonia com os demais seres. ${ }^{28}$ Com essa nova linha de pensamento, há quem traduza a Ética Ambiental como uma conduta de comportamento do ser humano com a natureza, cuja base está na conscientização ambiental e no compromisso preservacionista, com o objetivo de conservação da vida global. $^{29}$

Uma ética ecológica efetiva pressupõe uma cosmologia que fundamente uma cosmovisão que nos devolva a vivência de um mundo rico por si mesmo e não pela valoração pragmática que dele fazemos. ${ }^{30}$

De acordo com o paradigma antropocêntrico clássico, o ser humano é visto como senhor e possuidor da natureza. O antropocentrismo pode ser resumido como a tendência ético-filosófica que percebe o ser humano como centro e senhor da existência, num sentido em que todo o resto dos seres e processos orgânicos e

\footnotetext{
${ }^{28}$ SANTOS JR., Hidejal N. Artigo: "Ética Ambiental - Paradigma ou Conduta Profissional"

${ }^{29}$ Idem.

${ }^{30}$ MILARÉ, Edis e COIMBRA, José de Ávila Aguiar. "Antropocentrismo x Ecocentrismo na ciência jurídica". In Revista de Direito Ambiental. N.36: 09 - 41. São Paulo: Revista dos Tribunais, 2005, p. 36
} 
inorgânicos adquirem valor comparativamente ao homem e à utilidade que possam lhe proporcionar. ${ }^{31}$ Desse entendimento decorrem uma série de conseqüências insustentáveis para a manutenção de um ambiente ecologicamente sustentável, como a apropriação dos recursos naturais de forma absoluta, a identificação da natureza como fonte inesgotável de utilização humana, ou seja, a natureza é reduzida a mero objeto de investigação a ser dissecado e fragmentado para "benefício" exclusivo do ser humano.

Já o biocentrismo, contrariamente, nega, o antropocentrismo e defende uma relação igualitária entre os seres e um valor intrínseco à natureza, desvinculado de condições utilitárias. ${ }^{32}$ Sob esse prisma, qualquer dano tem uma dimensão biológica e ética acentuada, uma vez que o menor impacto, de uma forma ou de outra, estará rompendo um dos frágeis fios da Teia da Vida. ${ }^{33}$

Essa discussão é de fundamental importância, pois dependendo do entendimento a respeito da relação entre os seres humanos e a natureza, do papel que desempenham os seres humanos frente à comunidade biota, várias ações poderão ser tomadas e responsabilizadas amplamente ou terem seu campo abrangência diminuído, frente à

\footnotetext{
${ }^{31}$ LIMA, Gustavo F. da Costa. Ob. Cit., p.201-202.

${ }^{32}$ Ibidem, Idem.

${ }^{33}$ CAPRA, Frijof. A teia da vida: uma compreensão científica dos sistemas vivos. São Paulo: Cultrix, 1996. p. 25.
} 
necessidade humana. ${ }^{34}$ Dentro de uma perspectiva do ambientalismo global, os que defendem o antropocentrismo, em geral, entendem a questão ambiental como subproduto indesejável do progresso e a crença na ciência faz com que não se preocupem com os impactos ambientais. Por detrás do paradigma antropocêntrico-utilitarista está o pensamento liberal-individualista, que concorre para a exploração predatória da natureza pela ausência de preocupação com o coletivo, visto que a natureza é tida como algo exterior ao ser humano.

Cabe salientar ainda que há outras ramificações dessas correntes de pensamento que não se pretende analisar nesse trabalho. Limitar-seá a apresentar essas duas perspectivas básicas, predominantes no pensamento ocidental, suficientes, a priori, para se compreender a insuficiência do antropocentrismo para a manutenção da qualidade ambiental e a necessidade urgente de uma nova concepção que situe o ser humano como parte da natureza, rompendo com a tradição cartesiana que dicotomizou homem e natureza. ${ }^{35} \mathrm{E}$, além disso, se faz presente a necessidade de rever o paradigma antropocêntrico utilitarista e enfrentar as contradições do sistema jurídico que, nas palavras de ANNELISE MONTEIRO STEIGLEDER, apresenta conceitos e definições

\footnotetext{
${ }^{34}$ STEIGLEDER, Annelise Monteiro. Responsabilidade civil ambiental: as dimensões do dano ambiental no direito brasileiro. Porto Alegre: Livraria do Advogado Editora, 2004. p.20

${ }^{35}$ Não poderia deixar de mencionar o surgimento do antropocentrismo alargado que preceitua a proteção ambiental a partir de uma noção de integração do ser humano com o meio, sem todavia, atribuir um valor intrínseco ao meio ambiente. ANNELISE MONTEIRO STEIGLEDER destaca o Antropocentrismo Alargado como sendo uma das duas principais correntes de transição para o paradigma biocêntrico, e a outra seria o que se conhece por Deep Ecology (Ecologia Profunda). A ecologia profunda reconhece o valor intrínseco de todos os seres vivos. .P. 17 Muitos autores diferenciam a possibilidade de defesa e existência de um paradigma biocêntrico, da validade e pertinência do biocentrismo jurídico. A meu modo de ver, o antropocentrismo alargado mantém presente a redução do meio ambiente a utilidade humana, com a convicção da superioridade dos interesses humanos face aos interesses ambientais.
} 
jurídicas artificiais, cuja existência é meramente nominal, como instrumento do pensamento, sem o compromisso de traduzir a realidade. ${ }^{36}$

A mudança da concepção antropocêntrica do Direito para a revisão do princípio biocêntrico por si só amplia o conceito de meio ambiente, a fim de incluir neste, além dos componentes ambientais naturais, o ser humano enquanto criatura e os componentes ambientais humanos - ou seja, não apenas o ambiente natural, mas também o construído. Dessa forma, o Direito ambiental tem como cerne regular as relações do ser humano com a natureza, o que o difere fundamentalmente dos outros direitos que têm como premissa a regulação das relações dos seres humanos entre si.

Um dos pontos centrais e mais emblemáticos da postura biocêntrica é ver a natureza como um sujeito de direitos, e não apenas objeto de direitos, reconhecendo-lhe dignidade própria e, até mesmo, podendo opor aos seres humanos direitos fundamentais. ${ }^{37}$ A partir dessa premissa, que reconhece um direito à igualdade biocêntrica atribuível a todos os seres, decorrem uma série de outros valores que rompem de vez com o paradigma cartesiano dominante, principalmente no que se refere à refutação do dualismo estabelecido entre sujeito e objeto. Temse que reconhecer o fato de que a visão da natureza como objeto não tem sido capaz de responder as necessidades de preservação atuais.

\footnotetext{
${ }^{36}$ STEIGLEDER, Annelise Monteiro. Ob. cit. p. 23

${ }^{37}$ STEIGLEDER, Annelise Monteiro. Ob. cit. p. 87.
} 
Dentro do conceito jurídico clássico consagrado no Código Civil, a relação direta do ser humano com a coisa exprime uma relação de submissão, sendo o sujeito de direito o senhor do objeto podendo o proprietário privar-se jurídica e fisicamente das coisas e mesmo destruílas. Isto evidencia mais uma vez o equívoco do antropocentrismo jurídico, na medida que, na realidade, espera-se que os seres naturais, dispondo de um valor próprio, sejam capazes de se afirmar como sujeito jurídico, passando de objeto a sujeito da tutela.

A indeterminação subjetiva dos interesses difusos implica, também, na satisfação dos interesses da coletividade como um todo, da mesma forma que sua lesão se concretiza para todos. Assim, a fruição desses direitos não é exclusiva de algum titular, pois disseminada indistinta e eqüitativamente entre todos, devendo todos os mecanismos jurídicos existentes para a sua tutela adequar-se a esta característica, pela especial força que assume um direito fundamental com assento na Constituição, como é o caso do direito ao meio ambiente ecologicamente equilibrado, bem de uso comum do povo e essencial à sadia qualidade de vida, conforme disciplina o artigo 225 da Constituição Federal brasileira de $1988 .^{38}$

\footnotetext{
${ }^{38}$ Apesar de não estar inserido no capítulo dos direitos e deveres individuais e coletivos, isso não afasta seu caráter de direito fundamental, entendido como uma nova projeção do direito à vida e fundamental a dignidade da pessoa humana. De acordo com LUZIA DO SOCORRO SILVA DOS SANTOS, para verificar se um direito pertence à categoria dos direitos fundamentais não importa sua localização no texto constitucional. Sugere a mesma que o critério para adequadamente identificá-los é a presença das seguintes características: historicidade, universalidade, limitabilidade, concorrência, irrenunciabilidade e subjetivação. (In Tutela das diversidades culturais regionais à luz do sistema jurídico-ambiental. Porto Alegre: Sérgio Antonio Fabris Ed., 2005, p. 64).
} 
Sendo de interesse comum, afeto a todos, indistintamente, assume um caráter de indisponibilidade. Desta forma, não se pode limitar sua abrangência só quanto aos sujeitos envolvidos, mas também quanto aos objetos atingidos. Os interesses difusos têm um caráter de efemeridade, o que exige uma prestação jurisdicional imediata e eficaz, sob pena de irreparabilidade da lesão. $A$ análise das características dos interesses difusos é imprescindível para que possamos entender a necessidade premente de mudanças estruturais na prestação jurisdicional e na forma processual de lidar com a tutela ambiental, conforme está se expondo.

Por mais que o Direito seja produzido pelos seres humanos e para os mesmos, somente a partir da compreensão das peculiaridades dos interesses difusos tutelados pelo Direito Ambiental é que se pode entender a necessidade da mudança de paradigmas do Direito Clássico, a fim de buscar soluções alternativas aos conflitos ambientais, uma vez que já não é na natureza do homem (ou seja, na razão) que se procura o fundamento da norma, mas na harmonia cósmica, de que o homem é um simples componente. Nesse sentido, se faz imperante o reconhecimento de que a natureza inteira é sujeito: "ela quer, ela manda, ela condena, ela perdoa, e nós somos seus filhos".

A dimensão coletiva dos fenômenos sociais, entre outros fatores merecedores da tutela jurisdicional, torna ineficazes os esquemas tradicionais de ação judiciária, dificultando o pleno exercício da liberdade de acesso à justiça. ${ }^{39} \mathrm{~A}$ tutela dos interesses difusos ${ }^{40}$, a exemplo do

\footnotetext{
${ }^{39}$ MOREIRA, Danielle de Andrade. Ob. cit. p. 02.
} 
direito ao meio ambiente ecologicamente equilibrado e da proteção ao consumidor, traduz, de plano, como grande obstáculo a seu acesso, as dificuldades relacionadas à sua organização e, conseqüentemente, à sua representatividade. ${ }^{41}$

Com bem se sabe com o reconhecimento desses direitos coletivos e difusos se fez necessário incorporar ao Direito instrumentos que possibilitassem essa tutela diferenciada, revolucionando em certa medida o direito tradicional, ao prever como parte legitima para ingressar em juízo associações, por exemplo, de modo a representar interesses de toda uma coletividade. Da mesma forma que se construiu esse raciocínio para se adaptar a uma necessidade eminente, pode-se admitir a personalização da Natureza, atribuindo-Ihe a condição de sujeito de direito, com fundamento no valor simbólico da personalidade jurídica, de modo que seja viável a defesa judicial dos interesses da natureza tornarse independente da iniciativa do proprietário.

STONE, C. chama atenção para o fato de que houve um tempo em que os escravos e as mulheres também não eram sujeitos de direitos, de modo que, por mais que possa parecer inconsistente e até absurdo, a primeira vista, pensar na natureza e seus elementos como sujeitos de direito, em uma dimensão histórica, inclusive, pode-se admitir que o

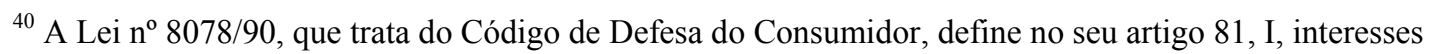
difusos como: "os transindividuais, de natureza indivisível, de que sejam titulares pessoas indeterminadas e ligadas por circunstâncias de fato".

${ }^{41}$ Ibidem, idem.
} 
direito evolua e passe a reconhecer o direito dos seres vivos em geral pleitearem em juízo ${ }^{42}$ pelas próprios reflexos que isso traria.

Conforme expõe DANIELLE DE ANDRADE MOREIRA, "o biocentrismo deve prevalecer, em detrimento do antropocentrismo, ao menos do ponto de vista ético e como fator de reconhecimento do valor intrínseco do meio ambiente, esse entendido como valor que independe do interesse e do próprio reconhecimento humano" ${ }^{43}$

\footnotetext{
${ }^{42}$ STONE, C. Should Trees have Standing? Toward Legal Rights for Natural Objects. Southern California law Review, 1972, citado por OST, ob. cit., p.199, que por sua vez, foi citado por STEIGLEDER, Annelise Monteiro, ob. cit. p. 90.

${ }^{43}$ MOREIRA, Danielle de Andrade. Ob. cit. p.42.
} 


\section{2 - CONCEPÇÕES DE MEIO AMBIENTE}

\subsection{Sentido e abrangência do termo}

De uma forma geral, o conceito que se tem de meio ambiente na atualidade é amplo e incorporando suas várias dimensões. Mas durante muito tempo o conceito de meio ambiente era reduzido à idéia de natureza stricto sensu, isto é, limitado aos seus elementos materiais que a compõe, tais como a flora, a fauna, o solo entre seus outros microbens ${ }^{44}$. Até hoje há muitas pessoas que não tem noção da abrangência e amplitude do termo. Corrobora para esse entendimento limitado do significado de meio ambiente a posição de ambientalistas radicais, altamente criticada, fundamentada em um conservadorismo desmedido que acaba por separar o ser humano da natureza, como se natureza e sociedade fossem planos distintos.

Ao mesmo tempo, essa concepção limitada de meio ambiente tem uma série de outras repercussões na sociedade à medida que coloca em xeque o ser humano com os demais elementos da natureza, como se o ser humano não fosse parte do meio ambiente. Assim, se discute de forma infundável e inconsistente possíveis contrapontos entre seres humanos e meio ambiente. Para exemplificar, por mais que seja esdrúxula a situação, muito já se falou na "necessidade" de se manter uma fábrica funcionando, apesar de poluir e contrariar as normas ambientais, por conta do número de funcionários que seriam demitidos e,

\footnotetext{
${ }^{44}$ Entende-se por microbem ambiental, a concepção de meio ambiente reduzida aos elementos que o compõem (florestas, rios, propriedade de valor paisagístico, etc.).
} 
portanto, ficariam sem trabalho afrontando o princípio da dignidade humana. Mas, na verdade, nessa análise simplória e reducionista, se esquece de levar em conta os reais problemas que estão no cerne da questão. Não é porque os funcionários precisam de um emprego, que se pode admitir que a fábrica possa poluir. A empresa que deve se adequar às normas existentes, antes de tudo, pois do que adianta os funcionários permanecerem empregados e a empresa funcionando se por outro lado põe em risco a saúde dos mesmos, em última instância o meio ambiente ecologicamente equilibrado, bem de uso comum do povo e essencial à sadia qualidade de vida está ameaçado. ${ }^{45}$

Paralelamente, como já foi falado, a concepção antropocêntrica de meio ambiente coloca o ser humano como medida de todas as coisas, separando também o ser humano da natureza, só que dessa vez subordinando a natureza a objeto de seu controle e superioridade, como se o ser humano não fizesse parte do meio ambiente, de forma que pode dominá-lo e usá-lo para se beneficiar como bem entender. Essa visão faz com que, erroneamente, também se contraponha meio ambiente e ser humano, de modo que se valoriza a ação humana desassociada da qualidade ambiental - que, em última análise, vai repercutir na própria qualidade de vida de todos os seres vivos, inclusive do ser humano.

\footnotetext{
${ }^{45}$ Uma vez que se entenda realmente o ser humano como integrante do meio ambiente, não há como se estabelecer essa contraposição entre meio ambiente e ser humano, pois, remetendo a situação exposta, seria inadmissível a complacência de um meio ambiente poluído com a presença humana. $\mathrm{O}$ direito ao meio ambiente sadio é base do bem-estar humano e da possibilidade de fruição de todos os direitos inerentes à condição humana, inclusive para o exercício laboral. Conforme expõe Liliana Allodi Rossit e Carla Canepa, é de fundamental importância que todos percebam a proteção ambiental como instrumento para a proteção da vida, por isso o direito ao meio ambiente sadio é base do bem-estar humano e da possibilidade de fruição de todos os direitos inerentes à condição humana. Artigo: $\mathrm{O}$ direito ao meio ambiente ecologicamente equilibrado como direito fundamental. Revista de direito constitucional e internacional no. 42. p. 245.
} 
Esclarecidas essas formas apartadas de enxergar a relação entre seres humanos - meio ambiente e partindo para a sua concepção no sentido de macrobem ambiental, o meio ambiente se destaca dos vários bens materiais em que se firma, de modo a garantir o equilíbrio e a integridade do ambiente, vislumbrado como patrimônio de toda a coletividade e fonte de recursos que propiciam o desenvolvimento da vida em suas várias dimensões. Conforme ressalta ANTÔNIO HERMAN BENJAMIN:

\begin{abstract}
"como macrobem, o meio ambiente é enxergado como verdadeira universitas corporalis (...) não se confundindo com esta ou aquela coisa material que o forma, manifestando-se, ao revés, como o complexo de bens agregados que compõem a realidade ambiental." 46
\end{abstract}

O meio ambiente, portanto, deve ser visto como uma realidade dinâmica, onde há uma relação de interdependência entre todos os seus elementos, o que origina e fundamenta preceitos éticos de extrema relevância, ${ }^{47}$ conciliando suas dimensões de macro e microbem.

Voltando a essas duas formas de entender a relação entre seres humanos - meio ambiente citadas anteriormente, ora pelo prisma preservacionista-extremista, ora sob o enfoque utilitarista-antropocêntrico, pode-se situar o fortalecimento do biocentrismo insurgente, que reconhece direitos intrínsecos a própria natureza, hostilizando o

\footnotetext{
46 BENJAMIN, Antônio Herman. "Função ambiental”. In Dano Ambiental - Prevenção, Reparação e

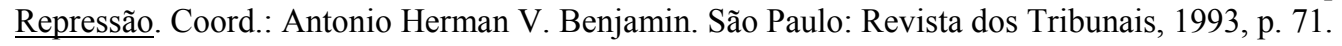

${ }^{47}$ MOREIRA, Danielle de Andrade. Ob. cit. p. 23.
} 
pragmatismo de matriz humanista. ${ }^{48}$ Admitir a vida em todas as suas formas de manifestação como centro do universo faz com que se amplie automaticamente a concepção de meio ambiente e se perceba o ser humano como parte integrante desse sistema. Ao invés de se pensar a questão ambiental isolada do ser humano ou o ser humano sobrepujando a natureza, o biocentrismo possibilita a natureza ser reconhecida como sujeito de valores e desse entendimento decorrem uma série de conseqüências muito importantes para a manutenção de um ambiente sadio conforme o exposto no capítulo anterior.

\section{2 - Conceito legal de meio ambiente}

No direito positivo brasileiro, a proteção jurídica ao meio ambiente encontra amparo legal em diversos dispositivos legais, mas, fundamentalmente, no artigo 225 da Constituição Federal de 1988 e na Lei 6.938/81 percebe-se um tratamento articulado de modo a proteger o ambiente como um valor em si. Em ambos os textos se constata uma responsabilidade social perante o meio ambiente, colocando o ser humano como integrante da comunidade biota, claramente perceptível na Lei $6.938 / 81{ }^{49}$ e que faz com que a solidariedade e comunhão de interesses entre ser humano e natureza sejam condição imprescindível para assegurar o futuro da humanidade no planeta.

\footnotetext{
${ }^{48}$ ANTUNES, Paulo de Bessa. Direito Ambiental. Rio de Janeiro: Lúmen Júris, 2001, p. 20.

${ }^{49}$ MORATO LEITE, José Rubens; AYALA, Patrick de Araújo. "A transdisciplinaridade do direito ambiental e a sua equidade intergeracional”. In Revista de Direito Ambiental. N.22. São Paulo: Revista dos Tribunais. p.68.
} 
A Lei 6.938/81, que instituiu a Lei da Política Nacional do Meio Ambiente traz uma definição ampla de meio ambiente, considerando-o como tudo que permite, abriga e rege a vida, então meio ambiente englobando todas as formas de manifestação da vida. No seu artigo $3^{\circ}, \mathrm{l}$, a Lei da Política Nacional do Meio Ambiente conceitua meio ambiente como:

"Conjunto de condições, leis, influências e intervenções de ordem física, química e biológica, que permite, abriga e rege a vida em todas as suas formas".

Partindo dessa definição apresentada pelo ordenamento jurídico brasileiro, o meio ambiente deve ser visto como uma realidade dinâmica, onde há uma relação de interdependência entre todos os seus elementos, o que origina e fundamenta preceitos éticos de extrema relevância. ${ }^{50}$ Além dessa definição federal, a maioria das conceituações estaduais de meio ambiente também engloba todas as formas de vida. ${ }^{51}$

JOSÉ AFONSO DA SILVA define meio ambiente como "a interação do conjunto de elementos naturais, artificiais e culturais que propiciem o desenvolvimento equilibrado da vida em todas as suas formas" ${ }^{52}$

\footnotetext{
${ }^{50}$ MOREIRA, Danielle de Andrade. Ob. cit. p. 23.

${ }^{51}$ MACHADO, Paulo Affonso Leme. Direito Ambiental Brasileiro. 10a . Ed. Rev., Atual. e Amp. São Paulo: Malheiros, 2001, p.131.

${ }^{52}$ SILVA, José Afonso da Silva. Direito Ambiental Constitucional. $2^{\text {a }}$ ed., revista. São Paulo: Malheiros Editores, 1998, p. 02.
} 
A Constituição Federal, em seu capítulo dedicado ao meio ambiente, utilizou a locução meio ambiente para indicar o "bem de uso comum do povo e essencial à sadia qualidade de vida". O direito ao equilíbrio ecológico, garantido na Constituição Federal, resulta da preservação da vida em todas as suas formas. A ruptura desse equilíbrio gera a degradação da qualidade ambiental e repercute na "sadia qualidade de vida". 53

O caput do artigo 225 da Constituição da República Federativa do Brasil assim dispõe:

\footnotetext{
"Todos têm direito ao meio ambiente ecologicamente equilibrado, bem de uso comum do povo e essencial à sadia qualidade de vida, impondo-se ao Poder Público e à coletividade o dever de defendê-lo e preservá-lo para as presentes e futuras gerações".
}

A par dessas duas referências legais, pode-se entender meio ambiente como o todo complexo de interações e relações entre o mundo natural e os seres vivos, contemplados tantos os aspectos naturais quanto os artificiais e os culturais. ${ }^{54}$ ROXANA CARDOSO BORGES salienta que:

"a teoria jurídica precisa sempre ampliar o conceito de meio
ambiente, não o considerando como natureza stricto sensu,
mas como sendo relações de dimensões sociais, econômicas,
urbanas e naturais nas quais vivem a pessoa e os demais
seres". $^{55}$

\footnotetext{
${ }^{53}$ ROSSIT, Liliana Allodi e CANEPA, Carla . Ob. Cit., p. 250.

${ }^{54}$ MOREIRA, Danielle de Andrade. Ob. cit. p. 22.
} 
2.3 - Aspectos do Meio Ambiente: natural, cultural, urbano ou artificial e do trabalho

Partindo de uma visão integrada de meio ambiente, admite-se a existência de vários aspectos resultantes das interações dos elementos naturais com os construídos, sem que isso afaste a sua concepção unitária.

De acordo com JOSÉ AFONSO DA SILVA, o meio ambiente pode ser classificado sob esses quatro aspectos: meio ambiente natural; cultural; artificial e do trabalho. ${ }^{56}$

O meio ambiente natural se traduz nos elementos responsáveis pelo equilíbrio entre os seres vivos e o seu meio. É formado pelos elementos bióticos e abióticos, necessários para a manutenção do equilíbrio do ecossistema global. LUZIA DO SOCORRO SILVA DOS SANTOS ressalta que o parágrafo $4^{\circ}$ do artigo 225 da nossa Constituição Federal de 1988 elege alguns desses ecossistemas como patrimônio nacional: Amazônia brasileira, Mata Atlântica, Serra do Mar, Pantanal e Zona Costeira. ${ }^{57}$

\footnotetext{
${ }^{55}$ BORGES, Roxana Cardoso Brasileiro. Ob. cit. p. 19.

${ }^{56}$ SILVA, José Afonso da. Direito Ambiental Constitucional. $2^{\mathrm{a}}$ ed. rev. São Paulo: Malheiros, 1998. p.03.

${ }^{57}$ SANTOS, Luzia do Socorro Silva dos. Tutela das diversidades culturais regionais à luz do sistema jurídico-ambiental. Porto Alegre: Sérgio Antonio Fabris Ed., 2005, p. 49.
} 
Já o meio ambiente cultural pode ser entendido como o conjunto de coisas criadas a partir de uma ação humana, diferente da natureza entendida como o conjunto de coisas que nos foram dadas. Essa diferenciação se faz necessária para que seja possível entender o aspecto cultural do meio ambiente. A princípio, a natureza poderia ser vista como o conjunto de todas as coisas que existem, mas quando contraposta à cultura se faz mister esse estreitamento do conceito. Considerando um sentido restrito de cultura, essa pode ser vista como o conjunto do patrimônio cultural brasileiro, o que engloba o patrimônio histórico, artístico, arqueológico, paisagístico e turístico.

O meio ambiente artificial diz respeito a todo e qualquer espaço urbano construído, consubstanciado no conjunto de edificações e equipamentos públicos. De acordo com CELSO ANTONIO PACHECO FIORILLO, o meio ambiente artificial visa integrar a pessoa à realidade econômica do país, a fim de possibilitar o exercício do trabalho na elaboração de produtos e serviços. ${ }^{58}$ Para CONSUELO YOSHIDA , a cidade constitui em si mesma um bem ambiental, identificando-a com as pessoas e seu habitat de modo a proporcionar as condições para o pleno desenvolvimento no sentido do bem-estar, físico e psíquico de todos. ${ }^{59}$

\footnotetext{
${ }^{58}$ FIORILLO, Celso Antonio Pacheco. "Tutela do meio ambiente face de seus aspectos essenciais: os fundamentos constitucionais do direito ambiental". In Ação civil pública: lei 7.347/1985 - 15 anos. Coord. ÉDIS MILARÉ. São Paulo: Revista dos Tribunais, 2001, p. 101.

${ }^{59}$ YOSHIDA, Consuelo Yatsuda Moromizato. "Poluição em face das cidades no direito ambiental brasileiro: a relação entre degradação social e degradação ambiental". Tese de doutoramento. São Paulo: Pontifícia Universidade Católica, 2001, p. 52.
} 
O meio ambiente do trabalho envolve a proteção da saúde e segurança do trabalhador no seu ambiente de trabalho. A Constituição Federal de 1988 trata da questão no seu artigo 200, VII, destinando ao sistema único de saúde o dever de colaborar com a proteção do meio ambiente, compreendido o trabalho.

Há ainda quem considere o meio ambiente rural como mais um aspecto a ser levado em conta, como é o caso de LUZIA DO SOCORRO SILVA DOS SANTOS, uma vez que especificado constitucionalmente nos artigos 184 a 191, pelos quais se observa que o equilíbrio do ambiente humano centra-se na função social da propriedade da terra, que tem como um dos seus instrumentos a reforma agrária. ${ }^{60}$

Como ressalta LÚCIA REISEWITZ, essa classificação é um exemplo das múltiplas faces que se poderia apresentar da tutela jurídica do ambiente que serve como meio para garantir a qualidade e manutenção da vida em todas as suas formas. ${ }^{61}$

\footnotetext{
${ }^{60}$ SANTOS, Luzia do Socorro Silva dos. Op. cit., p. 51.

${ }^{61}$ REISEWITZ, Lúcia. Op. cit., p. 61.
} 


\section{3 - SOCIOAMBIENTALISMO}

\section{1 - Proteção jurídica da sociodiversidade e do patrimônio cultural}

Para dar início as questões envolvendo o socioambientalismo ${ }^{62}$ é interessante ressaltar, a priori, o significado e origem do termo, bem como o contexto em que se insere.

Até a década de 80 , as práticas dos movimentos ambientalistas estavam voltadas basicamente para combater e apoiar a preservação de ecossistemas naturais. ${ }^{63}$ Parte significativa das associações ambientalistas não tinha nenhum diálogo ou repercussão na população mais excluída, levando muito pouco em consideração as dimensões socioeconômicas da crise ambiental. ${ }^{64}$ É só a partir dos anos 80 que se percebe uma maior tendência das ONGs ambientalistas em aproximar-se das ONGs sociais.

Aos poucos as práticas culturais ambientalistas passam de um enfoque central nas denúncias para valorizar as alternativas viáveis de conservação dos ecossistemas. ${ }^{65}$ Com isso, nota-se o crescimento do

\footnotetext{
${ }^{62}$ De acordo com o Almanaque Brasil Socioambiental, o socioambientalismo é um movimento brasileiro e o significado da palavra socioambiental não tem tradução literal para nenhuma outra língua e precisa ser interpretada pela idéia que transmite. p. 375

${ }^{63}$ Almanaque Brasil Socioambiental, ISA, 2005. p. 375

${ }^{64}$ Almanaque Brasil Socioambiental, p. 375

${ }^{65} \mathrm{O}$ marco diferenciador dessa situação é a passagem de práticas que podem ser definidas como reativas para práticas proativas. Almanaque Brasil Socioambiental, p. 376
} 
número de entidades não-governamentais e movimentos sociais que incorporam a questão ambiental a sua agenda de atuação, como pode ser percebido com a interação das ONGs com o movimento indígena, acoplando à luta tradicional dos índios pela proteção das suas terras, a preservação do meio ambiente; a aproximação de setores do Movimento dos Sem Terra, incluindo a variável ambiental na luta pelo acesso a terra, entre outros exemplos. ${ }^{66}$

O discurso que falava em proteção ambiental de forma isolada é substituído pela necessidade de pensar as relações entre 0 desenvolvimento econômico e a proteção ambiental, hipótese antes rejeitada pelos ambientalistas e que a partir, principalmente, da Rio-92, com o surgimento da idéia de desenvolvimento sustentável, vem a tona. ${ }^{67}$

Nesse contexto, promulgada a Constituição Federal brasileira de 1988, garantiu-se uma série de direitos coletivos e especiais, que configuram a base para o socioambientalismo e o direito socioambiental como se entende hoje. ${ }^{68}$

Reconhecido pela Constituição brasileira, o Direito Socioambiental trata conjuntamente as questões sociais e ambientais, mostrando que estão intimamente relacionadas. ${ }^{69}$ A Constituição de 1988 valorizou a

\footnotetext{
${ }^{66}$ Almanaque Brasil Socioambiental, p. 375.

${ }^{67}$ Almanaque Brasil Socioambiental, p. 376.

${ }^{68}$ Almanaque Brasil Socioambiental, p. 378.

${ }^{69}$ ARAÚJO, Ana Valéria. Almanaque Brasil Socioambiental, p. 190.
} 
nossa diversidade cultural e garantiu a todos os cidadãos o direito de ver este imenso patrimônio cultural protegido. Com isso, estabeleceu as bases de um direito moderno, o direito socioambiental, que se caracteriza por um novo paradigma de direitos da cidadania, passando pelos direitos individuais e indo muito além. ${ }^{70}$

O direito socioambiental parte da constatação de que não há razão de ser em conjuntos de direitos isolados e estanques, tão pouco adianta proteger o meio ambiente sem considerar o direito das populações que o conformam e são capazes de ajudar a mantê-lo protegido. ${ }^{71}$ Como ressalta ANA VALÉRIA ARAÚJO:

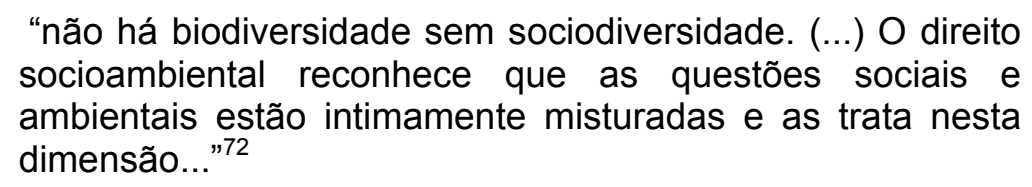
socioambiental reconhece que as questões sociais $e$ ambientais estão intimamente misturadas e as trata nesta dimensão..."72

Associada à rica biodiversidade brasileira, há o seu extenso patrimônio sociocultural: uma das populações mais diversificadas do mundo formada por povos indígenas, descendentes de quilombos, colonos, caiçaras, ribeirinhos, extrativistas, populações rurais e urbanas de diferentes origens étnicas e culturais. ${ }^{73}$

\footnotetext{
${ }^{70}$ ARAÚJO, Ana Valéria......, p. 190.

${ }^{71}$ ARAÚJO, Ana Valéria.....p.190.

${ }^{72}$ ARAÚJO, Ana Valéria....p.190.

${ }^{73}$ Dados extraídos do folder institucional do Instituto Socioambiental
} 
A noção de diversidade biológica traz consigo o componente cultural, que é o traço característico do ser humano e um dos componentes de seu habitat, e deve figurar igualmente no rol dos assuntos relativos à proteção internacional do meio ambiente global, a título de preservar-se a biodiversidade, e por seu turno, a sociodiversidade.

Nesse sentido, a Convenção da Diversidade Biológica é referência em âmbito internacional e também com muitas repercussões internamente. No campo interno, o legislador tratou especificamente da biodiversidade e da sociodiversidade, esta última intrinsecamente associada à primeira, nos artigos $215, \S 1^{\circ}$, e $225, \S 1^{\circ}$, II, do texto constitucional.

JULIANA SANTILLI ressalta que as comunidades indígenas, entre outros grupos participantes do processo civilizatório nacional, gozam de direitos territoriais e culturais especiais, assegurados constitucionalmente. ${ }^{74}$

É notória a importância das comunidades tradicionais na conservação da diversidade biológica. Estudos comprovam serem os povos indígenas e as populações tradicionais responsáveis, em grande

\footnotetext{
${ }^{74}$ SANTILLI, Juliana. Biodiversidade e conhecimentos tradicionais associados: novos avanços e impasses na criação de regimes legais de proteção. In: Revista de Direito Ambiental n. 29. p. 84, jan-mar de 2003. Assim como a autora, ressalto os artigos 231 e 232 da Constituição Federal de 1988 que tratam dos direitos indígenas, e o artigo 68 das Disposições Constitucionais Transitórias que assegura às comunidades negras, remanescentes de quilombos, direito à propriedade definitiva das terras que estejam ocupando.
} 
parte, pela diversidade biológica de nossos ecossistemas, produto da interação e do manejo da natureza em moldes tradicionais. ${ }^{75}$

Muito se tem discutido sobre as formas mais apropriadas de proteção ao conhecimento tradicional associado à biodiversidade, a repartição dos benefícios, entre outros assuntos relacionados ao tema. No Brasil, antes da edição da Medida Provisória 2.052, de 30.06.2000, em que o Poder Executivo atropelou o processo em desenvolvimento, diversos setores do próprio governo e da sociedade civil discutiam a formulação de propostas legislativas visando à implementação da Convenção da Diversidade Biológica, em vigor no país desde a sua ratificação pelo Congresso, em $1994{ }^{76}$

Posteriormente foi editado pelo Presidente da República o Decreto 4.339, de 22.08.2002, que instituiu princípios e diretrizes para a implementação da Política Nacional da Biodiversidade, com fulcro aos compromissos assumidos pelo Brasil ao assinar a Convenção da

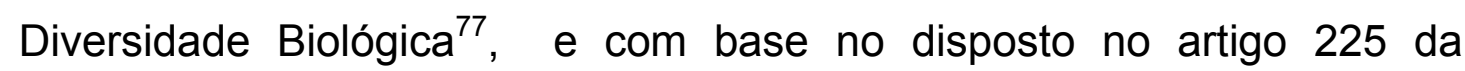

\footnotetext{
${ }^{75}$ SANTILLI, Juliana. Ob. cit, p. 85, ao citar ARAÚJO, Ana Valéria. "Acesso a recursos genéticos e proteção aos conhecimentos tradicionais associados", publicado na coletânea $O$ direito para o Brasil socioambiental, organizada por André Lima e editada pelo Instituto Socioambiental e por Sergio Antonio Fabris, Porto Alegre, 2002.

${ }^{76}$ Tal Medida Provisória foi reeditada sucessivas vezes e atualmente está em vigor a Medida Provisória 2.186-16/2001, que dispõe sobre o acesso ao patrimônio genético, a proteção e o acesso ao conhecimento tradicional associado, a repartição de benefícios e a transferência de tecnologia para sua conservação e utilização.

${ }^{77}$ A Convenção da Diversidade Biológica foi firmada durante a Conferência das Nações Unidas sobre Meio Ambiente e Desenvolvimento - CNUMAD, em 1992, aprovada no Brasil pelo Decreto Legislativo 2, de 03.02.1994, e promulgada pelo Decreto 2.519, de 16.03.1998.
} 
Constituição Federal, na Lei $6.938 / 81$, que dispõe sobre a Política Nacional do Meio Ambiente, na Declaração do Rio e na Agenda 21.

A instituição de princípios e diretrizes para a implementação da Política Nacional da Biodiversidade no Brasil, conforme trata esse Decreto acima mencionado, faz parte dos principais compromissos assumidos pelos países membros da Convenção da Diversidade Biológica no que concerne ao desenvolvimento de estratégias, políticas, planos e programas nacionais relacionados à proteção da biodiversidade.

Antes de abordar propriamente o tratamento legal que é dado a Cultura, é interessante compreender o sentido e a abrangência do termo. Nesse sentido, é bastante expressiva a definição trazida por MIGUEL REALE:

\begin{abstract}
"Cultura é o conjunto de tudo aquilo que, nos planos material e espiritual, o homem constrói sobre a base da natureza, quer para modificá-la, quer para modificar-se a si mesmo. É desse modo, o conjunto dos utensílios e instrumentos, das obras e serviços, assim como das atitudes espirituais e formas de comportamento que o homem veio formando e aperfeiçoando, através da história, como cabedal ou patrimônio da espécie humana" 78 .
\end{abstract}

Então, a partir dessa definição entende-se que tudo o que é fruto da ação humana é cultura. Mas nem tudo que é considerado como cultura deve ser protegido, visto que para o Direito devem ser levados em consideração alguns critérios norteadores.

${ }^{78}$ REALE, Miguel. Lições preliminares de direito. 14 a ed., São Paulo: Saraiva, 1987, p. 25. 
Além da Constituição da República Federativa do Brasil de 1988 destinar um precioso capítulo do seu texto ao meio ambiente, também trata especificamente da cultura no mesmo Título VIII (Da Ordem Social), Capítulo III (Da Educação, Da Cultura e do Desporto), Seção II (Da Cultura) artigos 215 e 216 . Abaixo transcrevo os artigos mencionados para que possamos entender a completude do disposto:

Art. 215. O Estado garantirá a todos o pleno exercício dos direitos culturais e acesso às fontes da cultura nacional, e apoiará e incentivará a valorização e a difusão das manifestações culturais.

$\S 1^{\circ}$ O Estado protegerá as manifestações das culturas populares, indígenas e afro-brasileiras, e das de outros grupos participantes do processo civilizatório nacional.

$\S 2^{\circ} \mathrm{A}$ lei disporá sobre a fixação de datas comemorativas de alta significação para os diferentes segmentos étnicos nacionais.

Art. 216. Constituem patrimônio cultural brasileiro os bens de natureza material e imaterial, tomados individualmente ou em conjunto, portadores de referência à identidade, à ação, à memória dos diferentes grupos formadores da sociedade brasileira, nos quais se incluem:

I - as formas de expressão;

II - os modos de criar, fazer e viver;

III - as criações científicas, artísticas e tecnológicas;

IV - as obras, objetos, documentos, edificações e demais espaços destinados às manifestações artístico-culturais;

$\mathrm{V}$ - os conjuntos urbanos e sítios de valor histórico, paisagístico, artístico, arqueológico, paleontológico, ecológico e científico.

$\S 1^{\circ}$ O Poder Público, com a colaboração da comunidade, promoverá e protegerá o patrimônio cultural brasileiro, por meio de inventários, registros, vigilância, tombamento e desapropriação, e de outras formas de acautelamento e preservação.

$\S 2^{\circ}$ Cabem à administração pública, na forma da lei, a gestão da documentação governamental e as providências para franquear sua consulta a quantos dela necessitem.

$\S 3^{\circ}$ A lei estabelecerá incentivos para a produção e o conhecimento de bens e valores culturais. 


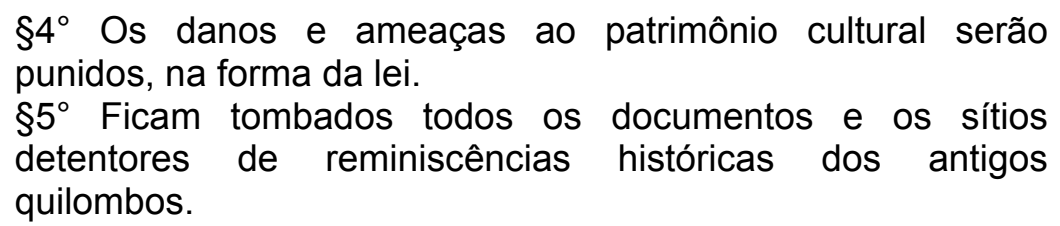

Como podemos extrair da leitura do artigo 216 da Constituição Federal de 1988, transcrito acima, a conceituação de patrimônio cultural brasileiro fornecida é ampla e nos permite, segundo PAULO AFFONSO LEME MACHADO, ${ }^{79}$ "uma proteção dinâmica e adaptável às contingências e transformações da sociedade".

Ele nos chama atenção para a distinção que é feita do caput do art. 216 com os seus quatro incisos de modo que apresentam a relação de bens de natureza material ou imaterial que podem ou não se relacionar com os grupos formadores da sociedade brasileira. ${ }^{80}$ Então, os bens incluídos nesses incisos podem ser protegidos mesmo que não tenham direta ou indiretamente vínculos à identidade, à ação e à memória dos grupos formadores da sociedade brasileira.

Também os locais de valor histórico ou artístico podem ser enquadrados nos valores estéticos em geral, cuja degradação afeta também a qualidade ambiental.

A noção de patrimônio cultural do art. 216 da CF é que irá dar fundamentação para a competência concorrente prevista no art. 24, VII. $\mathrm{O}$ art. 24 trata de uma competência diferente da competência apontada

\footnotetext{
${ }^{79}$ MACHADO, Paulo Afonso Leme Machado, p. 854.

${ }^{80}$ Idem, p. 853.
} 
no art. 23 e, assim, vemos que o texto do inc. III do art. 23 ao se referir a "paisagens naturais notáveis" não pode limitar ou modificar o campo de maior abrangência do art. 216, que não exige a condição de notabilidade para a paisagem ou outro sítio natural ser protegido.

Em relação a competência, a nossa Constituição Federal de 1988 estabeleceu, no art. 24, que:

\footnotetext{
"compete à União, aos Estados e ao Distrito Federal legislar concorrentemente sobre: VII - proteção ao patrimônio histórico, cultural, artístico, turístico e paisagístico".
}

A competência concorrente está subordinada às regras fixadas nos quatro parágrafos do referido art.24. A União deverá limitar-se a estabelecer normas gerais no que concerne à proteção dos bens e valores apontados no inc. VII, quando se tratar de normas que deverão ser obedecidas pelos Estados e pelos Municípios. Os Estados poderão suplementar as normas gerais federais (art. $24, \S 2^{\circ}$ ). Inexistindo as normas federais, os Estados poderão exercer a competência legislativa plena, para atender a sua peculiaridades (art. $24, \S 3^{\circ}$ ). A eficácia da lei estadual será suspensa com a superveniência de norma federal, no que Ihe for contrário (art.24, $\$ 4^{\circ}$ ). (Paulo Affonso Leme Machado. p. 869, do seu Manual).

A execução da legislação incumbe ao mesmo tempo à União, aos Estados e aos Municípios (art.23, III e IV, da CF), sendo que os Municípios têm o precípuo dever de "promover a proteção do patrimônio histórico-cultural local" (art. 30, IX, da CF). A competência para legislar 
sobre a matéria é concorrente à União e aos Estados (art. 24, VII), cabendo aos Municípios a legislação de caráter local e suplementar.

Entende-se que o termo patrimônio cultural envolve todo o mundo da cultura, consubstanciado em tudo aquilo em que o ser humano deposita seus valores, determinando sua relação com a natureza e com as outras pessoas, reconhecendo as peculiaridades dos vários segmentos da sociedade. ${ }^{81} \mathrm{O}$ tombamento é uma das formas de proteção do patrimônio cultural.

Conforme ressalta LÚCIA REISEWITZ, por meio da preservação do patrimônio cultural estamos exercitando nosso direito à memória, direito do qual depende a nossa sobrevivência histórica, importante para a construção da cidadania, da identidade nacional e da soberania. Recairá o direito à preservação no que concerne ao meio ambiente cultural, sempre que ele for meio para garantir a vida em todas as suas formas.

O Decreto 3.551, de 04.08.2000, institui o Registro de Bens Culturais de Natureza Imaterial, bens que constituem o patrimônio cultural brasileiro. Esse Registro será feito em quatro livros: Livro do Registro dos Saberes; Livro do Registro das Celebrações; Livro de registro das Formas de Expressão; e o Livro de Registro de Lugares. "A inscrição num dos livros de registro terá sempre como referência a continuidade histórica do bem e sua relevância nacional para a memória, a identidade e a formação da sociedade brasileira" (art. $1^{\circ}, \S^{\circ}$ ).

${ }^{81}$ ARAUJO, Luiz Alberto David e NUNES JR, Vidal Serrano....... 
As fontes de cultura nacional são manifestações culturais que não necessariamente se confundem com o patrimônio cultural brasileiro. A cultura é sobretudo um valor e, como tal seu entendimento é subjetivo. Já o significado de patrimônio, de acordo com o artigo 216 da Constituição brasileira, transcende os limites do valor monetário. Para o direito civil tradicional brasileiro, o patrimônio cultural sempre esteve ligado a bens que têm valor econômico. No entanto com essa definição da Constituição Federal brasileira temos uma acepção de patrimônio ampla, que engloba não só coisas materiais e imateriais, como valores materiais e imateriais, e monetários.

Por sua vez, no campo internacional, é importante mencionar a definição de patrimônio natural dada pela Convenção Internacional Relativa à Proteção do Patrimônio Mundial Cultural e Natural, $17^{\text {a }}$ Sessão da Conferência Geral das nações Unidas para a Educação, Ciência e Cultura, Paris, de 10 de outubro a 21 de novembro de 1972, aprovada pelo Congresso Nacional a 30 de junho de 1977 e promulgada pelo Decreto 80.978, de 12.12.1977.

Essa Convenção Internacional traz subsídios para dar os contornos dos monumentos naturais, sítios e paisagens a serem tombados no Brasil. Para o Decreto-lei 25/37 não é qualquer local que mereça o tombamento, mas aquele que está dotado de notabilidade. Critério que não é muito preciso, uma vez que sítios e monumentos naturais comuns em determinada época passam a ser diferentes ou raros em outra época 
histórica, passando a merecer menção especial ou serem digno de atenção.

A preservação do patrimônio natural e cultural, que constitui o habitat do ser humano, decorre dos deveres de resguardar aquilo que não se pode reconstruir, uma vez destruído.

3.2 - Princípio do respeito à identidade, cultura e interesses das comunidades tradicionais e grupos formadores da sociedade

Insere-se entre os princípios fundamentais do direito ambiental, o princípio do respeito à identidade, cultura e interesses das comunidades tradicionais e grupos formadores da sociedade..$^{82}$ Como já foi abordado anteriormente, a concepção adotada de meio ambiente abrange tanto o meio natural, como o artificial e cultural.

Dentre os valores que podem ser atribuídos à natureza, o valor existencial pressupõe a valorização da natureza pela sua simples existência, independentemente de qualquer contribuição aos seres humanos. Nessa perspectiva prevalece a visão da natureza refletindo valores intangíveis, intrínsecos e éticos.

\footnotetext{
${ }^{82}$ MIRRA, Álvaro Luiz Valery. "Princípios Fundamentais do Direito Ambiental”, p.64.
} 


\section{CONCLUSÃO}

A visão da natureza como objeto não tem sido capaz de integrar as relações entre o social e o ambiental, nem tão pouco equacionar os grandes problemas ecológicos atuais. Nesse sentido, somente 0 biocentrismo possibilita a preservação da Natureza, em seu sentido mais amplo, valorizando a vida em todas as suas dimensões, inclusive, a vida humana.

É indispensável à construção de uma ética que nos permita viver de forma harmoniosa na Terra, entendendo a importância e o sentido de respeito a todos os seres vivos. Somente com a superação dessa visão de mundo que reduz os seres à condição de objetos, se torna possível alcançar um verdadeiro equilíbrio ecológico. Isso implica uma mudança radical na maneira de compreender a nossa identidade enquanto humanos e o nosso lugar no cosmos, entre os outros seres vivos.

Aprender a valorizar e se encantar com toda a gama de diversidade social e cultural que enriquece a experiência humana na terra e, ao mesmo tempo, superar as mazelas sociais existentes é um grande desafio que se faz presente. A dimensão sócioambiental cada vez mais ganha força nesse cenário multifacetário. Ao mesmo tempo, a ciência jurídica precisa acompanhar todo esse processo para atender os anseios sociais que se colocam. 
A ausência de compromisso dos conceitos jurídicos com a verdade e com a adequação ao real, que está na gênese do pensamento jurídico moderno e na formação de seus institutos, torna conflituoso o diálogo entre a Ecologia e o Direito, pois os crescentes impactos ambientais que ultrapassam as dimensões locais e as lesões individuais demandam soluções jurídicas diversas daquelas impostas por normas destinadas a regular relações jurídicas tradicionais. 


\section{BIBLIOGRAFIA}

Curso de Direito Constitucional Positivo". 20ª . ed., São Paulo, Revista dos Tribunais, 2002.

Almanaque Brasil Socioambiental, p. 375, 376, 378

ANTUNES, Paulo Bessa. Direito Ambiental. 5a . ed., rev., Rio de Janeiro: Lumem Júris, 2001.

ARAÚJO, Ana Valéria. Almanaque Brasil Socioambiental

ARAUJO, Luiz Alberto David e NUNES JR, Vidal Serrano

Artigo: Ética ambiental. Endereço eletrônico:

Liliana Allodi Rossit e Carla Canepa.

ASSIS, José Chacon de. Brasil 21. Uma Nova Ética para o Desenvolvimento. 6a. Edição. Publicação do CREA/RJ, 2001.

BECK, Ulrich. La sociedad Del riesgo: hacia uma nueva modernidad. Barcelona, Buenos Aires, México: Paidós, 1998, p. 90

BENJAMIN, Antônio Herman. "Função ambiental". In Dano Ambiental Prevenção, Reparação e Repressão. Coord.: Antonio Herman V. Benjamin. São Paulo: Revista dos Tribunais, 1993, p. 71. 
BORGES, Roxana Cardoso Brasileiro. "Direito Ambiental e Teoria Jurídica no final do século XX". In O novo em Direito Ambiental. Org.: Marcelo Dias Varella e Roxana Cardoso Borges. Belo Horizonte: Del Rey, 1998, p. 13.

BUARQUE, Cristovam. A desordem do progresso: o fim da era dos economistas e a construção do futuro. Rio de Janeiro, Paz e Terra, 1990.

CAPRA, Frijof. A teia da vida. São Paulo: Cultrix, 1999. p. 43

CARDOSO, Adauto. "A Utopia em Construção: Modernidade, ecologia e urbanização." In Brasil Território da Desigualdade. Org.: ANA CLARA TORRES e ROSÉLIA PIQUET. Rio de Janeiro: Jorge Zahar Editores, 1991, p. 114.

FIORILLO, Celso Antonio Pacheco. Tutela do meio ambiente face de seus aspectos essenciais: os fundamentos constitucionais do direito ambiental. In: Ação civil pública: lei 7.347/1985 - 15 anos. MILARÉ, Edis (coord.). São Paulo: Revista dos Tribunais, 2001, p. 101.

FREITAS, Vladimir Passos de. "A Constituição Federal e a efetividade das normas ambientais”. São Paulo, Revista dos Tribunais, 2000.

GRECO, Leonardo. "Competências Constitucionais em Matéria Ambiental”. In: Revista dos Tribunais. Nº68, 1993. 
GUIMARÃES, Roberto P. A assimetria de interesses compartilhados: América latina e a agenda global do meio ambiente. In: Ecologia e política mundial. LEIS, H. R. (org.). Rio de Janeiro, Vozes/Fase, 1991.

http://www.aultimaarcadenoe,com/direitoetica.htm

In: Introdução ao Gerenciamento de Recursos Hídricos / Arnaldo Augusto Setti:...[et al.]. Brasília: Agência Nacional de Energia Elétrica; Agência Nacional de Águas, 2001. p. 242)

In: Introdução ao Gerenciamento de Recursos Hídricos / Arnaldo Augusto Setti:...[et al.]. Brasília: Agência Nacional de Energia Elétrica; Agência Nacional de Águas, 2001.

In: LIMA, Gustavo F. da Costa. Revista Eletrônica "política e Trabalho" setembro 1997 / p. 201-202

LIMA, Gustavo F. da Costa. Revista Eletrônica "política e Trabalho" setembro 1997 / p. 201-202.

LUZIA DO SOCORRO SILVA DOS SANTOS In: Tutela das diversidades culturais regionais à luz do sistema jurídico-ambiental. Porto Alegre: Sérgio Antonio Fabris Ed., 2005, p. 64

MACHADO, Paulo Affonso Leme. Direito Ambiental Brasileiro. 10 ${ }^{\mathrm{a}}$. ed., rev., São Paulo: Malheiros, 2002. 
MACHADO, Paulo Affonso Leme. Direito Ambiental Brasileiro. 10ª . Ed. Ver., atual. E amp. São Paulo: Malheiros, 2001,

MILARÉ, Edis e COIMBRA, José de Ávila Aguiar. "Antropocentrismo $\mathrm{x}$ Ecocentrismo na ciência jurídica”. In Revista de Direito Ambiental. N.36: 09 - 41. São Paulo: Revista dos Tribunais, 2005

MILARÉ, Édis. Direito do Ambiente: doutrina, prática, jurisprudência, glossário. São Paulo: Revista dos Tribunais, 2001.

MIRRA, Álvaro Luiz Valery. "Princípios Fundamentais do Direito Ambiental"

MORATO LEITE, José Rubens; AYALA, Patrick de Araújo. "A transdisciplinaridade do direito ambiental e a sua equidade intergeracional". In Revista de Direito Ambiental. N.22. São Paulo: Revista dos Tribunais. p.68

MOREIRA, Danielle de Andrade. Ob. cit. p. 20.

REALE, Miguel. Lições preliminares de direito. $14^{\mathrm{a}}$ ed., São Paulo: Saraiva, 1987,

REISEWITZ, Lúcia. Op. cit., p. 61. 
ROSSIT, Liliana Allodi e CANEPA, Carla. "O direito ao meio ambiente ecologicamente equilibrado como direito fundamental". In: Revista de Direito Constitucional e Internacional N. 42, p. 249.

SANTILLI, Juliana. Biodiversidade e conhecimentos tradicionais associados: novos avanços e impasses na criação de regimes legais de proteção. In: Revista de Direito Ambiental n. 29. p. 84, jan-mar de 2003.

SANTOS JR., Hidejal N. Artigo: Ética Ambiental: Paradigma ou Conduta Profissional. Endereço eletrônico: http://www.saude.inf.br/etica.htm

SANTOS, Luzia do Socorro Silva dos. Tutela das diversidades culturais regionais à luz do sistema jurídico-ambiental. Porto Alegre: Sérgio Antonio Fabris Ed., 2005

SILVA, José Afonso da Silva. Direito Ambiental Constitucional. $2^{\mathrm{a}}$ ed., revista. São Paulo: Malheiros Editores, 1998, p. 02.

SILVA, José Afonso da. Direito Ambiental Constitucional. 2a . ed., rev., São Paulo, Malheiros, 1995.

SIQUEIRA, Josafá Carlos de. Ética e Meio Ambiente. $2^{a}$ edição. São Paulo: Edições Loyola, 2002 
STEIGLEDER, Annelise Monteiro. Responsabilidade civil ambiental: as dimensões do dano ambiental no direito brasileiro. Porto Alegre: Livraria do Advogado Editora, 2004

VASQUEZ, Adolfo Sanches. Ética. Ed. Civilização Brasileira, 25a edição. 2004.

VIOLA, Eduardo \& LEIS, Hector. Desordem global da biosfera e a nova ordem internacional: o papel organizador do ecologismo. In: Ecologia e política mundial. LEIS. H. R. (org.). Rio de Janeiro, Vozes/FASE, 1991.

YOSHIDA, Consuelo Yatsuda Moromizato. "Poluição em face das cidades no direito ambiental brasileiro: a relação entre degradação social e degradação ambiental". Tese de doutoramento. São Paulo: Pontifícia Universidade Católica, 2001, p. 52.

OUTRAS PUBLICAÇÕES

Conferência das Nações Unidas Sobre $O$ meio Ambiente e Desenvolvimento (1992), Agenda 21, Capítulo 18, 18.2. 